\title{
DEIXIS FOUND IN KAMIO YOUKO'S HANA YORI DANGO IN ENGLISH VERSION
}

\author{
Mariska Febrianti \\ University of Dehasen Bengkulu \\ rika.samsuar@gmail.com
}

\begin{abstract}
Deixis cannot be separated to language itself because deixis is a part of language. One of language forms in our environment are comics. It is the popular literary works that teenager read besides novel and short story. The objectives of this research can be further detailed as the following; (1) To find kinds of deixis that are in Kamio Yuoko's Hana Yori Dango. (2) To know the situation of deixis are in Kamio Youko's Hana Yori Dango. The design of this research is descriptive qualitative research. It describes deixis found in Hana Yori Dango comic. This research uses the descriptive qualitative research. The result of this research are; (1) The kinds of English deixis found in Hana Yori Dango comic are; eighty five person deixis, twelve place deixis, thirteen time deixis, thirteen social deixis, and seventeen discourse deixis. So, it can be concluded the the dominan deixis which is used in Hana Yori Dango comic is person deixis and the minor deixis is place deixis and (2) The dominant situation in Hana Yori Dango comic is utterance situation related to person and social deixis in finding. So, the theory of deixis analysis from Jaszczolt (2002, p.191) is sticked with the result of deixis found in Hana Yori Dango comic. In this study, the kinds of deixis most commonly found is person deixis. It indicates that the author extremely want to show the figures in the story of comic. It can be seen from the portion of conversation made by the author is simple and short utterance and also related to some elements in comic itself.
\end{abstract}

\section{Keywords : Deixis, Hana Yori Dango comic.}

Deixis tidak dapat dipisahkan dengan bahasa itu sendiri karena deixis merupakan bagian dari bahasa. Salah satu bentuk bahasa di lingkungan kita adalah komik. Karya sastra ini populer di kalangan remaja selain novel dan cerita pendek. Tujuan dari penelitian ini sebagai berikut; (1) Untuk mengetahui jenis deixis yang ada di Kamio Yuoko komik Hana Yori Dango. (2) Untuk mengetahui situasi dari deixis yang ada di Kamio Youko komik Hana Yori Dango. Penelitian ini menggunakan penelitian deskriptif kualitatif. Hasil penelitian ini adalah; (1) Jenisjenis bahasa Inggris deixis ditemukan di Hana Yori Dango komik; Delapan puluh lima person deixis, dua belas place deixis, tiga belas time deixis, tiga belas social deixis, dan tujuh belas discourse deixis. Jadi, dapat disimpulkan deixis yang dominan digunakan dalam Hana Yori Dango komik person deixis dan place deixis adalah yang paling sedikit dan (2) Situasi yang dominan di Hana Yori Dango komik adalah situasi ujaran yang berkaitan dengan person dan social deixis. Dalam penelitian ini, jenis deixis paling sering ditemukan adalah person deixis. Hal ini menunjukkan bahwa penulis sangat ingin menunjukkan tokoh-tokoh dalam cerita komik. Hal ini dapat dilihat dari bagian percakapan yang dibuat oleh penulis adalah ucapan 
sederhana dan pendek dan juga terkait dengan beberapa elemen dalam komik itu sendiri.

\section{Kata Kunci : Deixis, Komik Hana Yori Dango.}

\section{INTRODUCTION}

Communication is one of the most important matters for living aspects, especially for human. People do communicate in order to help us fulfill our needs, because we cannot get what we want without say it. Communication itself divided into two ways, such as : verbal and non-verbal. Writing letter, sending message via email or telephone are examples of non-verbal communication, where as the parties involving in the communication are not doing the communication orally.

Communication non-verbal is the most important things.

In such communication, they have to involve at least two parties to considered as speaker and the other one as the listener. Speaker and listener not always come from the same background, such as : gender, education, social background, status, and age. So, they may use various language style in speaking and sometimes it makes the sentence is hard to understand to another party who involves in speech event.

Imagine if speaker says "How are you?" when there are more than one listener. The speaker may not get direct answer from the listener because they cannot get which "you" that she is talking to. Another example if speaker says : "are you okay there?" when she asks to her friend in distance. She chooses the word "there" instead of "here" because it strongly refers to how the condition of the listener is. The word you and there here, indicate that a system of language which is means to point person, time, place, social, discourse, that is called as deixis. Based on explanation before, deixis also related to speaker, listener and also speech event and that way is deixis included in pragmatic study. While pragmatic as Yule (1996, p.3) stated that concern to study of meaning as communication of speaker and hearer that related to contextual meaning.

Conversation not only occurs in direct way by talk face to face but also indirect, for example write a message by telephone as tools. Then conversation happen in written and is influenced by imagination namely literary works like drama, short story, film, novel, etc. deixis has been issues in some studies because in many literary works contain pointing words. It is proved by some researchers that have investigated, such as : Bejo Sutrisno, M.Pd investigate deixis on interactional oral discourse with the title "Conversation Analysis Between Vegetable Seller and Buyers at A Complex of Taman Kintamani Tambun, Bekasi, Ike Endah Rachmawati, Diponegoro University Semarang entitled the use of person deixis in relation to politeness function, Rosmawaty from State University of Medan with her research analysis the use of the kind of deixis on Ayat-Ayat Cinta novel by Habiburrahman El-Shirazy, Deixis In Raditya Dika's Utterances In StandUp Comedy Show by Harna Malau and Lince Sihombing and Dimas Pramianto from University of Muria Kudus with his research Deixis Found in "One Piece" Comic. 
One of that researchers above used comic as the object of this research, therefore it supported the writer to choose comic in this study because it is also example of literary works besides novel, short story, poetry and drama but seldom be the object to investigate not only in linguistic even in literature.

Then, next point of writer conducts a research about deixis in Hana Yori Dango because manga comic from Kamio Youko very popular in teenager. It is proved by Hana Yori Dango won award of Shogakukon, that means best seller comic all of time in Japan. That is why the title of this research is Deixis Found in Kamio Youko's Hana Yori Dango in English Version.

Pragmatic is study about meaning that related to the context. It concern to study of meaning as communication of speaker and listener that related to contextual meaning, (Yule, p.3). Pragmatic has some aspects that should concern such as speaker, listener and context. As those considering that pragmatic also happen in conversation to communicate, there is study brought of it which called deixis.

Understanding the definition of deixis, many linguists have presented the definition of deixis. Jaszczolt (2002, p.191) stated that 'deixis' derives from Ancient Greek which means 'to show', 'to point out. Deixis is the phenomenon of encoding contextual information by means of lexical items of grammatical distinctions that provide this information only when paired with this context. In other words, it means lexicalizing or grammaticalizing contextual information, that is making it into obligatory grammatical or lexical distinctions. They give instructions to the addressee that context has to be consulted in order to grasp the meaning of the utterance.

In Another side, Fromkin in her book An Introduction to Language (1991, p.199) said that in all languages there are many words and expressions whose reference relies entirely on the situationsal context of the utterance and can only be understood in light of these circumstances. This aspect of pragmatics is called deixis . First and second person pronouns such as ; my, mine, you, your, yours, we, ours, and us are always deictic because their reference is entirely dependent on context. You must know who the speaker and listener are in order to interpret them.

According to Yule (1996, p.9) stated that deixis is a technical terms for one of the most basic things people do with utterances. It means 'pointing' via language. By knowing and understanding deixis, the reader can easily determine the aspects of deixis such as person, spatial or place, temporal or time, social and discourse deixis. Besides Fromkin et al. (1991, p.1) stated that deixis are those words in a language that entirely depend on context.

Furthermore, Cruse (2000, p.319) defined that deixis means different things to different people. Moreover, Davis (2000, p.3) said that deixis is equivalent to pointing. It derives from the same Greek. Brown \& Yule (2000, p.27) elaborated three root that occurs on digit, index, indexical namely expressions whose reference is a function of the context of their utterance. Some deictic forms like here, now, you, this and that are considered some of the most obvious linguistic elements which require contextual information for their interpretation. 
From the descriptions above, it can be concluded that deixis is changing of word or utterance that are in same context and the reference. It also not static and has function as pointing word and to replace current words.

According to Jaszczolt (2002, p.205), deixis has been classified in the literature as (1) person deixis; (2) place deixis; (3) time deixis; (4) discourse deixis; and (5) social deixis. Those kinds of deixis are discussed as follows:

\section{(1) Person deixis}

Person deixis encodes the role of participants in the speech event, such as speaker, addressee, other entities. Person deixis is encoded in pronouns: 'I' for the speaker, 'you' for the addressee, 'he', 'she', 'it', 'we', 'they', for others. Pronoun system different from language to language: different information is grammaticalized. Person deixis can be grasped only when we understand the roles of the speaker, source of the utterance, recipient, the target of the utterance, and hearers who are not addressees or targets. Only then can we successfully replace the pronoun and adjectives as in the examples of (a) by those in (b) or (c) in processing the utterance.

(a) Give me your hand.

(b) Give him your hand.

(c) I give him my hand.

(2) Place deixis

Place deixis encodes spatial locations relative to the interlocutors. Here we allocate demonstratives proximal and distal in English, and adverbs of place: 'here' and 'there'. Place deixis specifies the location relative to the speaker and the addressee as in 'ten meters further', 'ten miles east of here', 'here', 'there'. 'Here' as the unit of space the includes the place the location of the speakers at the time of the utterance or a location proximal to the speaker's location at the time of the utterance the place pointed at if the use of 'here' is gestural. In some cultures, demonstratives can be distinguished on principles other than distance from the speaker, such as (i) close to the addressee, (ii) close to the audience, (iii) close to persons not participating in the event as well as (iv) on the basis of directions - above, below, or even (v) visible-non-visible to the speaker or (vi) upriver-downriver from the speaker, depending on the system of conceptualizing space used in the particular language. Time deixis

\section{(3) Time deixis}

Encodes temporal units relative to the time of the utterance. Here we distinguish coding time (time of utterance) and receiving time (time of the recovery of the information by the hearer). Tense markers and adverbs of time ('now', 'tomorrow', 'next year') also belong to this category. Time deixis is also oriented towards the in discourse. 'Now' means the time at which the speaker is producing the utterance. It is the coding time, different from the receiving time, although in practice the events of coding and receiving are, with an allowed approximation, co-temporal. The deictic centre can be projected on to the addressee as in an example below. 'Now' refers to the time at which the addressee learns the truth, which follows the time at which the author of the letter coded the message. For example: You know the whole truth now. I knew it a week ago, so I wrote this letter.

(4) Discourse deixis

$$
\text { Discourse deixis encodes }
$$

reference to portion of discourse. Discourse deixis is not one of the 
basic deictic categories. By means of this device we can rever to portions of discourse, as in 'in the last paragraph', 'this story', sentence-initial 'therefore', 'in conclusion', 'anyway', 'all in all', where the reference is relative to the utterance.

(5) Social deixis

Social deixis encodes social relationships and other social distinctions. Social deixis concerns social relationships between participants, their status and relations to the topic of discourse. Relationships that are relevant in their type of deixis include these between the speaker and the addressee, between other participants, the speaker and the object spoken about and soon. Devices used for the purpose of this deixis include varying forms of address, pronouns of politeness, kinship terms and honorifics, in particular addressee and referent honorifics.

From the five types of deixis above, some linguists (Charles Fillmore, Stephen Levinson), in Jaszczolt, analyze all five types of deixis as instances of the same phenomenon. But discourse and social deixis seem to differ from the three basic categories of person, place and time deixis. They grammaticalize or lexicalize certain distinctions relative to context, but may not need context for interpreting them.

The theory to analyze semantic issues of natural language called as situations. Whereas situations semantic is an information theory, that seeks to understand linguistic utterances in terms of the information conveyed. It supported by Devlin and Rosenberg (1990, p.56) showed that situations theory could also be used to analyze language use from an action perspective. Besides that Barwise and Perry (1980, p.4) wrote of situations are parts of the world, clearly recognized in common sense and human language, because situations is not just of objects, properties, and relations. But objects having and standing in relations to one and the other. Events and episodes are situations in time, scenes are visually perceptions and facts are situations enriched or polluted by language. Therefore based on those descriptions, situations is the goal that provides some indication of manner in which method may be applied.

The basic idea of situationss is utterance. In the simplest version, analyzes utterances in terms of three situations, namely utterance situations, resource situations and focal situations.

a. Utterance situation is context in which the utterance is made and received. It related to speaker and listener.

b. Resource situation can become available for exploitation in various ways, such as by being perceived by the speaker, the objects of the some common knowledge about the world, the way world is, and built up by previous discourse.

c. Focal situation also known as described situation. Focal situation is part of the world the utterance is about like features of the utterance situation.

\section{METHOD}

In this research, the writer used descriptive qualitative method and critical analyzing which analyze and to identify every utterances in comic using deixis. The data analysis technique used in this research is descriptive qualitative. Whereas, descriptive qualitative is a technique stated by statement, quotation or 
description by explanation. It is used to give more clear description about the study qualitatively by choosing, considering, defining and arranging the fixed data.

Critical analyzing is an analyzing that make people to be more focus with main purpose of research, Macmillan (2001, p.38). Then the writer will describe the data which will answer two questions in statement of problem. Object of this research is manga comic by Kamio Yuoko entitled Hana Yori Dango in English version series. The writer used deixis theory based on Jaszczolt (2002, p.191) in data analysis as approach by following steps as follows:

1. Read the comic,

2. Underlined the utterance related to deixis, and code it.

3. Put the utterance on the table instrument,

4. Identified and separated it into each kinds of deixis,

5. Read more for next finding,

6. Analyzed the situation of deixis

7. Made conclusion the data which have been collected.

\section{FINDING AND DISCUSSION}

In this chapter consist of finding is found by the writer in Hana Yori Dango by Kamio Youko. After collecting the data, the types of deixis in Makino utterance in comic show are classified based on the types of deixis by Jaszczolt theory (2002, p.191). There are five types of deixis namely person deixis, place deixis, time deixis, social deixis, and discourse deixis. It is found that there were one hundred fourthy occurrences of deixis which are divided into eighty five person deixis, twelve place deixis, thirteen time deixis, thirteen social deixis, and seventeen discourse deixis. Here some examples of deixis :

It looks like he is leaving the school. He is here today to get his stuff. (p.3)

The utterance it above as example of person deixis as subject pronoun. Whereas it refers to the view of speaker saw at Makino's class. Then the word he also represent the example of person deixis as subject pronoun which Makino said to point her friend. In addition, it and he included into utterance situation because it refers to context in which utterance is made and received by Devlin and Rosenberg (1990, p.56). Makino made the utterance it to show the situation at class when her friend back to school just for collect his stuff and make her utterance can received by the listener. Then $h e$ as the utterance of Makino made to called her friend who did it.

I wear a fake smile every day. Myself, who didn't have the courage to talk to Kimotokun. To tell the truth, I hate myself most of all. (p.19)

The utterance most of all refers to the characterization of Makino who had changed after she becomes the students of Eitoku Academy. She can't be herself as Makino which brave, strong personality and never give up to problem she occur. That is why most of all included into discourse deixis. Based on the utterance which discourse deixis has, it can be found that it including to resource situation. It caused of the utterance describe or built up by previous act who happen before of speaker and hearer. 
What a childish and cruel game. And those bastards, the F4. (p. 8)

The word bastards including into social deixis because it showed status and relation of listener to speaker. According to example above, speaker used bastard to represent her point of view to F4. Besides that it also related to attitude of F4 in school. Therefore the utterance bastards included into social deixis

Moreover, based on the function of the utterance bastards in that example as listener who said by speaker, if connected to situation theory by Devlin and Rosenberg (1990, p. 56) it included into utterance situation. It can be liked that because bastards is part of listener or in the other word it represent as participant who received the utterance in speech event.

Based on the findings, many kinds of deixis are found in Kamio Youko's Hana Yori Dango comic. While, it divided into five types are person deixis, discourse deixis, social deixis, time deixis and place deixis. Kamio Youko as the author of that comic used deixis to arrange and avoid the repetition in conversation between each figures in there. Besides that, it also influenced by comic features which provide as location of author to put the conversation. That is why the utterance in comic contains with simple and short utterance of dialogue.

In this study, the kinds of deixis most commonly found is person deixis. It indicates that the author extremely want to show the figures in the story of comic. It can be seen from the portion of conversation made by the author is simple and short utterance and also related to some elements in comic itself. The finding supported by deixis theory according to Jaszczolt (2002, p.191) which stated that person deixis indicates the role of participants in speech event, such as speaker, listener, other entities. Person deixis has closely related to the reader to understand the role of speaker, source of utterance, recipient, the target of the utterance, and listener who are not the targets. For example:

This all started when he talked back to $\boldsymbol{f} \boldsymbol{4}$ in defense of another student. (p. 6)

Makino Tsukushi as central figure of Hana Yori Dango comic says certain utterance, she used person deixis by the author made to decrease the repetition in conversation. Like to called Domyouji, Rui, Nishikado and Mimasaka, she usually used them and F4 as person deixis in her conversation.

Furthermore, in situation theory based on Devlin and Rosenberg (1990, p. 56) there are three types of situation namely : utterance situation, resource situation and focal situation. Person deixis as the dominant kinds of deixis in Hana Yori Dango comic related to situation of that conversation made and received. In the other word, it can called utterance situation where as it concern to speaker and listener. Actually, in fact between three types of situation based on Devlin and Rothenberg theory, utterance situation also be the most situation is used because person deixis and added with social deixis be the most appears in Hana Yori Dango comic than the other. Person deixis and social deixis has closely related to subject or pronoun in conversation.

After that, discourse deixis is the second kinds of deixis which dominant appears in Hana Yori Dango 
comic. Discourse deixis can be related to conclusion of speaker dialogue in comic. It can be exist without the other aspect to built up. For example to say all of that in the dialogue the author need to add some previous discourse to support the deictic of discourse deixis. After the author elaborate that before, then discourse deixis appears to replace that.

In Hana Yori Dango comic, Kamio Youko as the author also used that point in her comic. She wrote some actions that acted by F4 to Makino, then to called that actions again Kamio used the utterance of discourse deixis. That case also happen in situation aspect. According to Devlin and Rosenberg theory (1990, p. 56) about types of situation, resource situation is related to discourse deixis. Resource situation is available for exploitation of perceived by speaker, the object of some common knowledge about world to built up by previous discourse. So resource situation are in discourse deixis.

On the other hand, the kinds of deixis is time deixis which relate to reference to participant and also distinguish the moment of utterance from moment of reception. The word indicates this kinds of deixis is adverb of time such as : today, the next morning, now, yesterday and tomorrow. That words are pointing changes of time when speaker says the utterance. Makino used the deictic of time deixis to show when the event happen.

The last kinds of deixis is place deixis. According to Jaszczolt theory (2002, p. 191), place deixis concern to location of participant in speech or dialogue. It connected to the deictic which indicate this deixis are here and there. Based on Hana Yori Dango comic, place deixis less used by Makino to the figure in that comic because some figures usually deliver the information to the other than mention about relative to location of participant.

Time deixis and place deixis interconnected each other in situation aspect. It cause of they have same function to described situation. As Devlin and Rosenberg (1990, p. 56) elaborate in their theory, part of the world that described the situation known as focal situation. Therefore time and place deixis including to focal situation. Based on Hana Yori Dango comic focal situation be the second dominant of types the situation after utterance situation. It is because after subject and object, adverb is also important aspect of sentence.

\section{CONCLUSION}

Based on the research, the writer found many deixis are in Hana Yori Dango by Kamio Youko. After collecting the data, the kinds of deixis in Makino utterance in comic show are classified based on the kinds according to Jaszczolt theory (2002, p.191). There are five types of deixis namely person deixis, place deixis, time deixis, social deixis, and discourse deixis. It is found that there were one hundred fourthy occurrences of deixis which are divided into eighty five person deixis, twelve place deixis, thirteen time deixis, thirteen social deixis, and seventeen discourse deixis.

It indicates that speaker and listener are important aspect in utterance of conversation. When person want to talk something or make a conversation, he need the listener as participant in speech event. It's not wrong if the conversation did not have listener as who received the topic but 
the purpose of speaker want to deliver in the utterance to make conversation can't be implement.

In another side, the chosen language of speaker and listener as participant said in society can reflect the status and social situation. It can called as social deixis. From the definition social deixis has similar to person deixis but in social deixis, there are statuses or social situation that consider in society. Social deixis is used by the author in Hana Yori Dango comic related to difference social situation Makino has central with her friends status at school.

There are seventeen discourse deixis which found by the writer in Hana Yori Dango comic. It can be seen that in comic also concern to the use of expression by the utterance refers to portion of discourse content although the author used simple and short utterance in conversation.

There are thirteen time deixis refers to the moment of utterance from moment reception. The words which indicate time deixis are tomorrow, now and yesterday. And there are twelve place deixis related to spatial location of participants in speech. It usually used here or there as indicate the location. Time deixis and place deixis have similar function to describe situation in comic.

From the situation that author emphasizes in the utterance, person deixis and social deixis included into utterance situation with the role related to context in which utterance made and received. In another word, it related to the situation of speaker and listener in the utterance. Then, discourse situation included into resource situation because resource situation is available for exploitation of perceived by speaker, the object of some common knowledge about world to built up by previous discourse. Lastly, time and place deixis included into focal situation that known as described situation. Time and place deixis are represented by adverb in the utterance that has function to explain the situation. That is the reason time and place deixis related to focal situation.

Therefore, based on explanation above comic still has the same aspect to another literary works like novel, short story, film, etc. Besides the difference characteristic of comic with short and simple utterance, it still concern to purpose and the rules to built good sentence in conversation. In generally, the author of comic used deixis and utterance situation as dominant finding in this research to show the figures that followed by certain situation in story.

\section{REFERENCES}

Barwise, J. and Perry. The Situation underground, in Stanford Working Paper in Semantics. Sag, Stanford Cognitive Science Group. 1980.

Cruse, D. Alan. Meaning in Language: An Introduction to Semantic and Pragmatics. Oxford: Oxford University Press. 2000.

Davis, B20nd.www.usersurvey. (n.d).Retrived March 20, 2009, from

http://www.slideshare.net/yusu $\mathrm{f} \_\mathrm{k} / \mathrm{deixis}$-concept

Devlin and Ronsenberg, D. Language at work : Analyzing Communication Breakdown in the Workplace to Inform Systems Design, Stanford 
University : CSLI Publications and Cambridge University Press. 1996.

Fromkin, Victoria and Robert Rodman, H and Hyyams, N. An Introduction to Language. Massachusetts: Thompson Wadsworth. 1991.

Jaszczolt, K.M. Semantics And Pragmatics . Longman. 2002.

Macmillan and Bell, Suzanne. Teaching with Educational Technology in the 21st Century. United Stated America : Information Science Publising. 2001.

Yule, George. Pragmatics. New York: Oxford University Press. 1996. 